\title{
CELOWOS̃Ć W PRZYRODZIE W UJĘCIU PIOTRA P. GRASSÉ
}

W literaturze filozoficznej $\mathrm{i}$ : biologicznej pojawia się ciągle zagadnienie celowości i przypadku w naturze. Spór o celowość odgrywa wielką rolę w historii filozofii aż do dzisiejszych czasów. Według :H. Sachsse’a trudno osiągnąc zgodę $\mathrm{w}$ tym sporze, ponieważ nastawienie do tego problemu jest w dużym :stopniu nasycone światopoglądowymi i społecznymi postawami ${ }^{1}$. Dla filozofii, pisze J. Hass, nie jest to tylko problem akademicki, ponieważ może być rozpatrywany w głębszej perspektywie, jako związany z problematyką Pierwszej Stwórczej Przyczyny powstania i rozwoju życia na Ziemi. Filozofia przyrody nie może jednak rozwiązywać tego zagadnienia w oparciu o same rozumowe przesłanki, bez uwzględnienia najnowszych wyników biologicznych badań ${ }^{2}$. P. P. Grassé idzie w tym osądzie jeszcze dalej i twierdzi, że filozofia nie poczyni żadnego postępu, jeżeli nie posłuży się zdobyczami nauk:przyrodniczych ${ }^{3}$. Ważną przeto dla filozofa przyrody rzeczą jest zapoznanie się $\mathrm{z}$ wypowiedziami biologów na temat celowości w ożywionej przyrodzie.

Celem niniejszego artykułu jest właśnie zapoznanie się z koncepcją celowości w przyrodzie francuskiego biologa Piotra P. Grassé ${ }^{4}$. Na początku swych rozważań Grassé zaznacza, że jest biologiem, a nie filozofem, a to pozwala 'lepiej zrozumieć przebieg jego myśli, dotyczących zagadnienia celowości w przyrodzie. Przez ,,przyrodę” czy „,naturę” rozumie Grassé całość wszystkich materialnych bytów ożywionych i nieożywionych, z których składa się kosmos, oraz ogół praw, jakie nim rządzą i jakim jest poddany cały wszechświat ${ }^{5}$. Rozważania swe ogranicza jednak autor tylko do przyrody ożywionej.

1 H. S a chs se, Kausalität - Gesetzlichkeit - Wahrscheinlichkeit, Darmstadt 1979, s. 13.

2 J. Ha a s, Das organische Leben. Sein Wesen und Herkunft, [w:] Gott, Mensch, Universum, Graz-Wien-Köln 1974, s. 336, 325, 451.

3 P. Grassé, Das Ich und die Logik der Natur. Die Antwort der modernen Biologie, München 1973, s. 11.

4 Grassé jest członkiem Akademii Nauk i profesorem na Wydziale Nauk w Paryżu. Ogłosił kilkaset prac o strukturze komórek i z zakresu etologii.

5 P. Gras sé, jw., s. 10, 14. 
1. PORZĄDEK, DETERMINIZM, PRADOPODOBIEŃSTWO, PRZYPADEK

Zagadnienie celowości wiąże Grassé z zagadnieniem porządku w naturze. Uniwersalny porządek jawi się z całą jasnością badaczowi w każdym zjawisku przyrody. Badacz stwierdza przez to uporządkowanie wszechświata i odkrywa prawa rządzące zjawiskami. Swiadoma czy nieświadoma wiara w uporządkowany kosmos leży, według autora, u podstaw każdego naukowego badania i każdej idei przewodniej kierującej badaniami ${ }^{6}$. Porządek panujący $\mathrm{w}$ przyrodzie nie może być pomyślany bez ścisłego pośredniego czy bezpośredniego panowania zasady przyczynowości, a także bez przyjęcia determinizmu. Tam bowiem, gdzie kończy się determinizm, zaczyna się nieporządek. Zdaniem autora uniwersalne znaczenie determinizmu należy do credo ogółu przyrodników. Wprawdzie odkryto w fizyce kwantowej dziedzinę, w której determinizm zdaje się nie posiadać zastosowania, jednakże, według Grassé, i tu zasada determinizmu nie może być postawiona pod znakiem zapytania. W uzasadnieniu powołuje się na rozróżnienie Maksa Plancka, według którego problem powiązania przyczynowego należy nie do świata doświadczenia, w którym każdy proces mierzenia podlega błędom, lecz do świata pomyślanego, choć równie rzeczywistego, przyjmowanego przez przyrodników poza światem doświadczenia. Właśnie na tym poziomie, pisze Grassé, przyrodnik może formułować prawa natury. Ilustruje to przykładem: Próżno szukalibyśmy konkretnej linii prostej, która odpowiadałaby dokładnie definicji linii prostej. Jednakże to nie stawia pod znakiem zapytania ani pojęcia linii prostej, ani twierdzeń związanych z tą definicją ${ }^{7}$.

Dla powstania porządku zasada przyczynowości odgrywa ważną, lecz nie jedynie rozstrzygającą rolę. Przyczynowość jest w pewnej mierze tylko aktorem, a nie reżyserem porządku. Wyłączając metafizyczne dyskusje Grassé stwierdza, że każde naturalne zjawisko posiada swoją przyczynę. Natomiast trzeba odróżnić zasadę przyczynowości od determinizmu, od którego właśnie pochodzi porządek w naturze. Jeżeli w jakimś procesie natury są znane przyczyny i jeżeli w bardzo wielkiej liczbie przypadków obserwujemy takie same skutki, tak że mogą uchodzić za przewidywalne, to $\mathrm{u}$ ich podłoża leży działanie determinizmu. Jednakże porządek nie powstaje w sposób konieczny z samej zasady przyczynowości i determinowalności poszczególnych zjawisk. Jeżeli poszczególne zjawiska są wprawdzie powiązane przyczynowo, lecz nie są skoordynowane ze sobą w żadnym punkcie, to nie można mówić o porządku. Inaczej mówiąc, porządek powstaje dopiero wtedy, gdy powstaje zależność między częściami całości, względnie między całościami, które znów tworzą razem wyż-

6 Jw., s. $13 \mathrm{n}$.

7 Jw., s. $15 \mathrm{n}$. 
szy porządek. Najogólniejsze fizykalne prawa, jakie zostały odkryte przez Newtona, Einsteina, Lorenza i innych, wskazują, zdaniem Grassé, na istnienie podstawowego porządku we wszechświecie. Prowadzi to do ogólnego wniosku, że uporządkowanie zjawisk zależy od ogólnych praw, które warunkują sposoby działania praw szczegółowych i determinują izolowane zjawiska. Wszechświat, jako anty-chaos, zależy więc od zasad wyższego porządku, a nie od czystej przyczynowości i koniecznych działań, wynikających ze stosunku pomiędzy różnymi prawami ${ }^{8}$.

Grassé stawia sobie pytanie, czy uporządkowanie świata da się pogodzić ze stosowalnością rachunku prawdopodobieństwa. Odpowiedź na to pytanie uważa za ważne, ze względu na rolę przypadku w naturze. Do 20. w., pisze Sachsse, uznawano powszechnie przyczynowe powiązanie procesów natury. Natomiast w 20. w. okazało się, że w pewnych dziedzinach ważne są prawa nie przyczynowe, lecz prawdopodobieństwa, co spowodowało rewolucję w przyrodniczym i filozoficznym myśleniu ${ }^{9}$. Odpowiedź dana przez Grassé na to pytanie jest pozytywna, gdyż uważa, że porządek natury jest całkowicie zgodny z prawami prawdopodobieństwa. Pozorna niedeterminowalność wielu biologicznych procesów nie wynika $\mathrm{z}$ ich natury, lecz z warunków, w jakich się je obserwuje. Wzięte jednak same w sobie okazują się jako ściśle zdeterminowane. Natomiast całość podlega statystycznemu prawdopodobieństwu. Otwiera ono liczne drogi, które prowadzą do różnych rozwiązań, jednak ich częstotliwość może być wyrachowana. Porządek jest przeciwieństwem nieporządku i chaosu, a nie prawdopodobieństwa.

Autor ilustruje swe rozważania procesem dziedziczenia barw przez rośliny. Jeżeli mamy dwa geny na różne barwy, to w poszczególnym przypadku nie możemy przewidzieć, która cecha wystąpi u rośliny. Jednakże fakt, że nie możemy przewidzieć pojedynczej cechy, nie zmienia niczego w stanie problemu, ponieważ mechanizm dziedziczenia podlega ścisłemu determinizmowi, co czyni możliwym przewidywanie całości z absolutną pewnością. Prawa Mendla dotykają tu tylko drugorzędnego problemu, oddającego ten stan rzeczy, że proces dziedziczenia otwiera przed organizmem różne możliwości. Natomiast sam proces dziedziczenia jest poddany we wszystkich przypadkach podobnemu determinizmowi. Reasumując Grassé stwierdza, że te i podobne zjawiska w przyrodzie nie stawiają pod znakiem zapytania ani zasady przyczynowości, ani determinizmu, chociaż prawidłowości, którym podlegają, są statystycznej natury. Każde zjawisko, które można przewidzieć na podstawie znanych praw, jest $\mathrm{z}$ całą pewnością zdeterminowane. Natomiast nie można powiedziéc a priori, że nie dające się przewidzieć zjawisko jest niezdeterminowane.

\footnotetext{
8 Jw., s. $16-18$.

$9 \mathrm{Sachs}$ se, jw., s. 110 .
} 
Autor uważa, że pomieszanie determinizmu z absolutną przewidywalnością prowadzi $\mathrm{w}$ wielu przypadkach, a także $\mathrm{i}$ w biologii, na manowce ${ }^{10}$.

Grassé przestrzega przed wyciąganiem fałszywych wniosków z istnienia porządku we wszechświecie. Mianowicie krytykuje ostro tych filozofów, którzy z istnienia porządku i jego nieodzowności w naturze wyciągają wniosek, że ewolucja jest czymś iluzorycznym. Zdaniem tych filozofów rzeczywiście istniejąca ewolucja stałaby w sprzeczności z porządkiem opartym na prawach, ponieważ prawa, którym podlega materialny świat, działają w kierunku utrzymania jego stałości, a nie w kierunku powstawania zmian. Nie wymieniając nazwisk filozofów Grassé twierdzi, że ewolucja i porządek nie stoją w stosunku sprzeczności do siebie. Określone bowiem zjawiska, które są zdeterminowane jako podlegające stałym prawom natury, powodują zmianę cech w materii. Ewolucja jest zgodna z działaniem praw, które od czasu do czasu zmieniają naturalny stan równowagi i powodują przez to powstawanie nowych form ${ }^{11}$. Mamy pewność, że życie nie jest anarchistyczne. Ewolucja odkrywa swój realny porządek i czyni go przez to zrozumiałym. Ewolucja istot żywych nie jest źródłem zaburzeń, przeciwnie, przynosząc nowe formy zabezpiecza równocześnie porządek. Ewolucja nie jest rewolucją, czyli nie jest wyłamywaniem się śpod porządku. Nie można zapominać, że jest rodzajem historycznego zdarzenia i jako taka jest nieodwracalna ${ }^{12}$.

Dalsze pytanie dotyczy zagadnienia, czy uporządkowanie natury da się pogodzić z istnieniem przypadkowych zdarzeń. Problem jest ważny, ponieważ niektórzy biologowie przypisują przypadkowi rozstrzygającą rolę przy powstaniu życia i ewolucji gatunków. Według autora słowo „przypadek" oznacza zjawiska różnorodne i co do przyczyny, i co do ich natury. Grassé rozróżnia dwa typy przypadku: Pierwszy typ przypadku zachodzi wtedy, gdy między zjawiskami nie istnieje w ogóle żadne konieczne powiązanie. Przykładem takiego przypadku byłaby panmiksja dwóch grup zwierząt różnej płci. Nie można jednak tego powiedzieć o procesie zapładniania, ponieważ gamety łączą się na podstawie prawa determinizmu prawdopodobieństwa.

Drugi typ przypadku zachodzi wtedy, gdy krzyżują się dwie niezależne od siebie serie zdarzeń. Jest to jednak przypadek tylko w sensie nieprzewidywalności skrzyżowania się serii zdarzeń i nie oznacza niezdeterminowanych zdarzeń. Nazywanie tego typu przypadku zdarzeniami niezdeterminowanymi jest tylko czystą grą słów, ponieważ wszystkie zachodzące tu zdarzenia są zdeterminowane. Dlatego Grassé określa jako

10 P. Grassé, jw., s. 18-20.

11 Jw., s. 23.

12 Jw., s. 25. 
przypadkową tę sekwencję zdarzeń, której rezultatu nie możemy przewidzieć z całą pewnością. Bardzo małe, lecz nie równe zeru, prawdopodobieństwo czyni trudnym, a nawet niemożliwym, przewidywanie. Autor przyznaje, że rozumienie przypadku jako tego, czego nie możemy przewidzieć czy zrozumieć jest wysoce antropomorficzne. Pomimo tego nie stawia ono pod znakiem zapytania zasady przyczynowości i uniwersalnego determinizmu, natomiast zwalcza sentymentalną ocenę rzeczywistości. Czynienie z przypadku Boga i tłumaczenie nim zjawisk przyrody uważa Grassé za równoznaczne $\mathrm{z}$ przyznaniem się do nieumiejętności analizowania zdarzeń natury i ze składaniem broni przed trudnymi zagadnieniami ${ }^{13}$.

Już te pierwsze spostrzeżenia uważa Grassé za nie dające pogodzić się z twierdzeniem, że ewolucja doszła do skutku jako przypadkowe zdarzenie. Pomimo różnych meandrów ewolucja prowadzi zawsze do bardziej złożonych stanów. Wprawdzie ewolucja wykazuje także nieudane skutki, lecz przemiany są posłuszne prawom, które kierują porządkiem w naturze. Pewne formy wymarły właśnie dlatego, że popadły w sprzeczność z tymi prawami. Gdyby ewolucja była skutkiem przypadkowości, to próżno szukalibyśmy porządku w naturze. Ewolucja nie przebiega w każdym czasie i na każdym poziomie organizacji w ten sam sposób i w tym samym tempie. Autor uważa, że przeoczenie tego faktu prowadziło do błędnej oceny ewolucji. Wprawdzie ewolucja może prowadzić na boczne drogi, jednakże nie zmienia to jej podstawowych kierunków rozwoju ${ }^{14}$.

Ewolucja może być tym, czym jest tylko dlatego, że respektuje reguły, które zapewniają jej wewnętrzny porządek i wywierają rozstrzygający wpływ na los istot żyjących. Reguła ta nie dopuszcza m.in. do krzyżowania różnych linii rozwojowych niezależnie od tego, czy pochodzą od wspólnego korzenia, czy nie. Gdyby doszło między nimi do przypadkowego pomieszania, to zapanowałby chaos i nieporządek. Genetyczna izolacja była, jest i pozostanie podstawowym elementem biologicznego porządku. Przyznanie ewolucji uporządkowanego kierunku rozwoju nie implikuje wcale, według autora, że wierzy się w pewien rodzaj uprzedniego przeznaczenia, czy we wewnętrzną siłę, która prowadzi genealogiczny rozwój jak „,pociąg po szynach" 15 .

Gdyby ewolucja była dziełem przypadku, to w państwie zwierząt panowałby całkowity chaos i nieład form. Nawet przeciwnicy celowo ukierunkowanej ewolucji $\mathrm{w}$ rzeczywistości wierzą $\mathrm{w}$ nią i nieświadomie postępują według zasady celowości. Według autora nie jest wcale łatwym zadaniem próba wyjaśnienia porządku natury i jej ciągłego roz-

\footnotetext{
$13 \mathrm{Jw} .$, s. $21-23$.

14 Jw., s. $26-27$.

15 Jw., s. $29-30$.
} 
woju ku wyższym organicznym formom przez całkowicie przypadkowe i nieprzewidywalne zmiany (mutacje), które potem konserwuje lub odrzuca selekcja jak Deus ex machina. Głównym argumentem teoretyków przypadkowej ewolucji i w rzeczywistości jedynym, jest fakt, że dzisiaj nie obserwujemy $w$ naturze żadnych zmian genetycznych, jak tylko spontaniczne i przypadkowe mutacje, o których ani nie wiemy, jak powstają, ani nie możemy przewidzieć, których genów dotyczą. Powstawanie. mutacji uważają ci biologowie za rodzaj szczęśliwej gry. Wbrew temu Grassé uważa, że także powstawanie mutacji podlega determinizmowi, a tylko poszczególne człony jego działania nie są jeszcze znane i dlatego powstawanie i przebieg mutacji jest nieprzewidywalny ${ }^{16}$.

W obliczu faktu, że przypadkowe mutacje są dziedziczne, niektórzy biologowie twierdzą, iż pomimo pozornego celowego ukierunkowania ewolucja musi być interpretowana jako wynik przypadku, którego działanie koryguje i sprawia, że przeżywają tylko korzystne warianty. Grassé dziwi się temu uporczywemu trzymaniu się teorii, a pomijaniu wyraźnie przemawiających faktów. Jak można, pisze, wierzyć we wszechmoc naturalnej selekcji i jej uniwersalności, skoro można stwierdzić, że w tym samym środowisku żyją zgodnie obok siebie formy archaiczne z pochodzącymi od nich wyżej zorganizowanymi istotami. Heterogeniczność fauny w obrębie dokładnie ograniczonego biotopu jest faktem, który pozostanie niewyjaśnionym, jeżeli przypisze się selekcji nieograniczone działanie. To nie biolog, pisze autor, zaprzecza teorii przypadku, lecz fakty są z nią sprzeczne ${ }^{17}$.

Przypadkiem nie można także tłumaczyć skoordynowanej ewolucji licznych cech, które zakładają dla swego powstania wiele niezależnych od siebie mutacji. Według autora przyznają to sami zwolennicy teorii. przypadku. Podaje przykład G. Simpsona, znanego obrońcy teorii przypadku, który podał klasyfikację kopalnych form konia. Lecz klasyfikacja. ta wykazuje, zdaniem Grassé, nie tylko celową kierunkowość ewolucji, lecz także zsynchronizowaną i skoordynowaną zmianę licznych cech w rozwoju tej formy. Kto zaprzecza temu, pisze autor, ten albo systematycznie sprzeciwia się faktom, albo, co na jedno wychodzi, postępuje nieuczciwie. Paleontologia dostarcza dowodów na to, że ewolucja przebiega celowo. Ten stan faktyczny jest jasny dla wszystkich, a chodzi tylko o to, by go interpretować poprawnie. Przed faktami muszą ustąpić wszelkie teoretyczne zastrzeżenia i wyznania wiary. Kto nie chce tak postepować, ten według autora winien zrezygnować z uprawiania nauki ${ }^{18}$.

Biologowie przypisują selekcji rolę porządkującego czynnika, aby móc:

\footnotetext{
16 Jw., s. $30-31$.

17 Jw., s. $31-32,120$.

18 Jw., s. $32-33$.
} 
wytłumaczyć bieg ewolucji przez dowolne przypadkowe zmiany, które nie są związane bezpośrednio z procesem ewolucji. Teoria przypadku nie może jednak rozwiązać zadowalająco wielkich problemów ewolucji, pomimo że jest bardzo wysoko ceniona przez biologów i filozofów anglosaskich. Dla rozwiązania tego zagadnienia Grassé zwraca uwagę na aspekt porządku natury. Olbrzymie znaczenie porządku i organizacji nie występuje nigdzie tak jasno, jak w zjawiskach życia. Czasem mówi się, że właśnie to różni istoty żywe od martwych. Jednakże podział istot na organiczne i nieorganiczne $\mathrm{w}$ oparciu tylko o kryterium porządku nie jest wystarczające. Przemiana materii dokonuje się na rozkaz zawartych w chromosomach kwasów nukleinowych. Zawierają one w sobie plany struktury komórek, zawierają informację i są tym, co sprawia życie ${ }^{19}$.

Jakąkolwiek przyjmie się teorię życia, pisze Grassé, pozostanie fakt, że życie powstaje przez organizację, równowagę i porządek wewnątrz złożonego i heterogenicznego materiału budowy komórek. Porządek panuje pomiędzy wszystkimi częściami organizmu, istnieje na każdym poziomie, a więc na poziomie atomu, drobiny, makrodrobiny i organelli $\mathrm{w}$ organizmie. W zasadzie życie nie jest niczym innym, jak tryumfem porządku. Według niektórych filozofów z determinizmu i uporządkowania przyrody prowadzi rzekomo droga do materialistycznego poglądu na świat. Według autora - z faktu, że natura nie jest chaotyczna, lecz jest uporządkowana na wszystkich poziomach bytu według odpowiednich praw, można wyciągać i inne, filozoficznie przeciwne wnioski ${ }^{20}$.

Porządek w naturze, który odkrywamy krok za krokiem i wyrażamy w prawach rządzących określonymi dziedzinami, jest tak samo realny jak fizykalny świat. Bez istnienia porządku w naturze i bez praw, którymi się wyraża, byłaby niemożliwa każda nauka. Cóż bowiem mógłby odkrywać badacz w chaosie przypadków? Wszystko możliwe, pisze autor, tylko nie ogólne prawa. Badania pozwalają poznać, że świat istot żyjących nie jest chaotyczny, lecz jest poddany prawom, spod których nie może być wyjęta żadna istota 21 .

Teoria przypadku jest w zasadzie teorią przemian tego, co już istnieje, a więc nie przynosi rzeczywiście nowych osiągnięć. $Z$ wyjątkiem przypadkowego rozkładu genów przy mejozie, zapłodnieniu i mutacji, organizm podlega na poziomie komórki ściśle fizykochemicznym prawom. Prawa te nie mogą być usunięte bez śmierci organizmu. Gdyby ewolucja przebiegała bez wewnętrznych praw i była poddana tylko przypadkowym fluktuacjom, to musielibyśmy przyznać, że także rozumny człowiek, ostatnie ogniwo określonej linii ewolucji, byłby dzieckiem przypadku. Myśl

\footnotetext{
19 Jw., s. $33-34$.

20 Jw., s. $38-39$.

21 Jw., s. 54.
} 
ta, która była wypowiedziana przez filozofów już dawno temu, obraża rozum. Jest to tym bardziej jasne, jeżeli weźmiemy pod uwagę skomplikowany mózg i narządy zmysłowe człowieka. Czynienie z przypadku stwórczego Boga stanowi według autora niezwykłą naiwność i ślepą wiarę w hipotezę przypadku ${ }^{22}$.

\section{CELOWOŚC W NATURZE}

Szeroko jest rozpowszechniony pogląd, pisze Grassé, że determinizm i celowość nie dadzą pogodzić się ze sobą. Jest to jednak pogląd z gruntu fałszywy. Grassé powołuje się na Claude Bernarda, który wniósł duży wkład do przyjęcia determinizmu, a równocześnie skłaniał się do jawnego finalizmu w przyrodzie. Trudno przypuścić, pisze autor, że jego myślenie było obarczone sprzecznością. Finalizm nie tylko godzi się z determinizmem, lecz także zakłada go w dwojaki sposób: bezpośredni i pośredni.. W rzeczywistości bowiem obserwujemy dwojakie działanie celowości, jedno, które występuje natychmiast i bezpośrednio, oraz drugie, które objawia się dopiero w dłuższym działaniu. Właśnie celowość nadaje determinizmowi charakter nieuniknionej konieczności. Równocześnie bez determinizmu nie można by było wyobrazić sobie celow.ości, nawet gdyby się ją sprowadziło do rodzaju prymitywnego animizmu ${ }^{23}$.

Immanentna celowość godzi się także ze zmianami genetycznymi, które podlegają determinizmowi. Nauka o dziedziczności daje informację o utrzymywaniu i przekazywaniu cech, oraz o niektórych ich zmianach. Natomiast nie wyjaśnia rzeczywistego występowania nowych cech. Dziedziczność utrzymuje i przekazuje, ewolucja tworzy nowe cechy. Zarówno dziedziczenia jak i ewolucji nie można uważać za bezładne procesy, gdyż przez takie stawianie problemu fałszuje się rzeczywistość i dochodzi do sprzeczności. Wprawdzie uzyskiwanie nowych genów jest conditio sine qua non dla ewolucji, jednak tej nowości nie można tłumaczyć animizmem, według którego w pierwszych formach były już dane wszystkie geny w zalążku. Taką preformistyczną koncepcję życia odrzucają wszyscy naukowo myślący biologowie. Epigeneza dokonuje się i w onto- i w filogenezie i zdaje się być podstawowym sposobem działania istot żywych $^{24}$.

O biologicznej informacji, immanentnej celowości i przyczynach ewolucji wiemy jeszcze mało, by można było formułować przekonujące i ostateczne sądy. Autor podkreśla jednak jeszcze raz, że immanentna celowość godzi się doskonale z determinizmem, ogranicza jego działanie, kanalizuje go, i podwójnie zakotwicza. Celowość musi się przeto rozwa-

22 Jw., s. 123.

23 Jw., s. 39.

24 Tenże, Allgemeine Biologie, Bd. V: Evolution, Stuttgart 1973, s. 200. 
żać jako determinizm z podwójnym działaniem ${ }^{25}$. Struktura komórek, struktura organów i organizmu zdaje się słuchać programu i planu organizacji, który jest na zawsze zakotwiczony w dziedzicznym wyposażeniu gatunku. Życie rozwija się i utrzymuje według tego planu. Biologowie używają słowa „,architektura życia" na oznaczenie zorganizowanych i uporządkowanych według stałych reguł struktur. Mówiąc jednak o architekturze myślimy o planie, a ten jest pojęciem na wskroś finalistycznym ${ }^{26}$.

Działalność istot żywych nie jest ani dowolna, ani przypadkowa. Jest ukierunkowana na utrzymanie życia i rozmnażanie. Jest to fakt niezaprzeczalny i zawsze obserwowalny. Jest to fakt tak banalny, że często zapomina się o nim i nie zauważa się go. Innymi słowy żywe istoty posiadają w sobie wewnętrzną celowość. Grassé sądzi, że „wstydliwe i chełpliwe" pojęcia pseudoteleologii i teleonomii, których używają niektórzy biologowie, wyrażają dokładnie to samo, co pojęcie celowości. Wewnętrzna celowość wyraża się w mechanizmie samozachowania się, wewnętrznej asymilacji i rozmnażania się. To stwierdzenie nie implikuje żadnej filozofii, lecz po prostu jest stwierdzeniem faktu. Ta wewnętrzna celowość zdaje się być nową zdobyczą, wniesioną przez powstanie istot żywych.

Rozstrzygający jest fakt, że każde zjawisko życia otrzymuje swoje znaczenie przez włączenie w system wzajemnie połączonych procesów. Całość tych procesów prowadzi do ożywienia, nadaje systemowi życie. Każdy cykl życia implikuje początek i cel, który oznacza nie tylko kres, koniec, lecz także urzeczywistnienie ustalonego i zawsze takiego samego skutku. Przez integrację do jedności organizmu zjawisko życia uzyskuje swój sens i znaczenie, którego nie posiadałoby rozważane jako izolowane. Ten sens i znaczenie polega na tym, że indywiduum ma się utrzymać jako organiczna jedność i ma tę jedność pomnażać. Ta faktyczna celowość w porównaniu do transcendentnej może wydawać się skromną, lecz obiektywny, zobowiązany do prawdy obserwator, może zawsze stwierdzić jej istnienie. Zresztą musi brać ją pod uwagę, chociaż nie stara się podać jej określenia.

Grassé nie uważa immanentnej biologicznej celowości ani za tajemniczą zasadę, ani za bergsonowski elan vital, ani za entelechię, ani za działającą od zewnątrz niematerialną przyczynę, lecz po prostu uważa ją za podstawową własność istot żywych. W pewnym sensie nie byłoby przesadą twierdzenie, że jest ona samym życiem. Autor jest przekonany, że pogląd ten podzielają liczni biologowie. Życie nie jest pierwotną własnością materii. Pogląd, który tak je przedstawia, trzeba zwalczać jako zafałszowanie faktów. Życie jako takie jest czynnością uporządkowanego,

${ }^{25}$ Tenże, Das Ich, s. 46.

${ }^{26}$ Jw., s. 52. 
ustrukturalizowanego, złożonego systemu i jest to czynność ukierunkowana, której celem jast być żywym i żywym pozostać ${ }^{27}$.

To, czego nie może martwa materia, to czyni istota żywa. Walczy z siłą ciężkości, aby utrzymać równowagę. Nieożywiony przedmiot jest bezbronny wobec wpływów otoczenia, istota żywa przystosowuje się nieustannie do nich i umie obejść to, co sprzeciwia się jej czynnościom. Szczególnie charakterystyczne jest postępowanie istot żywych wbrew prawu entropii. Zdolność rozmnażania się jest tak znana, że nie spotrzegamy jej swoistości w stosunku do martwych przedmiotów. Przeciwieństwo między ożywionymi i nieożywionymi bytami jest tu nieprzekraczalne. Biologiczna celowość sytuuje się w samym życiu jako takim, choć istoty żywe nie są jej świadome. Według autora, słownik biologów i biochemików służący do opisania struktur i czynności makrodrobin, z których składają się istoty żywe, jest w wysokim stopniu finalistyczny. Biologowie mówią bowiem o modyfikatorach, efektorach, represorach, genach, operonach, przenoszeniu informacji itd. Autor dodaje, że każdy kod, a więc i genetyczny także, zakłada porozumienie między partnerami, przez co zakłada w sposób niezaprzeczalny celowość ${ }^{26}$.

Grassé nie czyni wyrzutu biologom molekularnym za ich hipotezy i terminologię, zaznacza tylko, że chcą czy nie chcą, ich sposób interpretacji życia nosi na sobie pieczęć uznanego czy nieuznanego, świadomego czy nieświadomego, czystego finalizmu. Używane przez nich słowo ,teleonomia" nie zmienia tu niczego. Właśnie w infrastrukturach, w wewnętrznych i najbardziej istotnych mechanizmach komórki występuje celowość z największą oczywistością. Celowość posiada bezpośredni związek z utrzymaniem życia. Jeżeli niektórzy twierdzą, że ta oczywista harmonia jest wynikiem działania szczęśliwego przypadku, to pomimo to muszą uznać fakt, że produkty przypadku stwarzają antyprzypadkowe systemy żywe. Grassé uważa za absurdalne przekonanie, że z przypadkowego może powstać zdeterminowane.

Można potępiać finalizm i obrzydzać go, pisze autor można występowá przeciw niemu, to jednak nie zmieni faktu, że wszelkie badania i eksperymenty są dokonywane $\mathrm{z}$ ukrytym założeniem finalizmu. Najbardziej zagorzali przeciwnicy celowości przyjmują ją jako hipotezę roboczą. Czy można, pyta Grassé, badać istoty żywe bez założenia, że wszystkie części organizmu, wszystkie organy, pełnią swą rolę i funkcję w utrzymaniu całości istoty żywej? Oczywiście, są organy niepożyteczne, pozostałe jako odpadki ewolucji, lecz to nie zaprzecza celowości struktur i czynności istot żywych. Błędny krok, pisze autor, hamuje biegacza, lecz nie zatrzymuje go w biegu. 
Stwierdzenie istnienia immanentnej celowości w świecie ożywionym nie musi prowadzić w sposób konieczny do uznania istnienia celowych przyczyn na poziomie biologii. Celowość immanentna, czy lepiej się wyrażając, faktyczna, jest czymś innym niż celowość transcendentalna. Pierwsza jest sprawą biologii i stanowi jej charakterystyczną swoistość, druga należy do metafizyki. To rozróżnienie nie znaczy, że problemu celowości transcendentnej nie można by było postawić w biologii ${ }^{29}$. Badacz natury, który stwierdza istniejący w przyrodzie porządek, musi się czasem zapytać, jaki mistrz wymyślił i stworzył ten porządek. Pytanie jest słuszne i uzasadnione, jednakże obchodzi ono nie naukę, lecz metafizykę ${ }^{30}$. Celowość, która nie jest transcendentalna, jest przeznaczona poniekąd tylko dla świata biologii, do jej wewnętrznego użytku i pomaga jej odróżnić świat biologii od makrokosmosu ${ }^{31}$.

Wyśmiewanie przez antyfinalistów ,wiecznej iluzji” celowości w przyrodzie, pisze Grassé, nie potrafi zmienić niczego w faktycznym stanie rzeczy. Według tezy antyfinalistów przystosowanie istot żywych do otoczenia łudzi tylko pozorną celowością, gdy w rzeczywistości jest produktem szczęśliwego i rzadko występującego przypadku, który ich zdaniem wypędza celowość jak ,święcona woda diabła”. Dla tych biologów ewolucja i adaptacja nie wykazują najmniejszych śladów celowości. Są bowiem dziełem przypadkowych mutacji, a przypadek ani nie dąży, ani nie osiąga żadnego celu. Mutacje, które okazują się korzystne dla przeżycia indywiduum i gatunku, utrzymują się i powielają dzięki działaniu naturalnej selekcji, a więc tworzą tylko pozór celowego ukierunkowania. Grassé sądzi odwrotnie, że selekcja jest tylko pozornie antyfinalistyczna, a w rzeczywistości jest $\mathrm{w}$ wysokim stopniu celowa. Wskazuje na to fakt, że ewolucja dokonuje się zgodnie z możliwie największą korzyścią indywiduum i gatunku ${ }^{32}$.

Pojęcie selekcji przykrywa tylko rzeczywiście istniejącą celowość. Biologowie przyjmujący teorię przypadku nie widzą, że implicite podstawiają w miejsce celowości wewnętrznej celowość transcendentną, ponieważ wybór jest zawsze połączony z celem i przyczyną celu. W zasadzie doprowadzają więc antyfinaliści celowość wewnętrzną aż do najbardziej zewnętrznej granicy, transcendującej poza świat biologii, a przez to unoszą się „w chmurach czystej metafizyki”. Finalizm, pisze autor, stanowi jakby wiecznie odradzający się "chwast" nauki, gdyż zaledwie wytrzebi się go w jednym miejscu, to jeszcze silniej odradza się w drugim. Szybciej niż feniks odradza się z popiołów. Na okrężnej drodze pojęć adaptacji, struk-

29 Jw., s. $49-50$.

30 Jw., s. 55.

31 Jw., s. $51-52$.

32 Jw., s. 53; tenże, Evolution, s. 92. 
turalnych i sterownicznych procesów powraca zawsze na nowo na scenę biologicznych dyskusji. Faktyczna celowość, jaką stwierdzamy w każdej żywej istocie, w każdym organizmie i biologicznym systemie, nie jest wynalazkiem ludzkiego ducha, lecz jest stanem rzeczowym. Zaprzeczyć jej znaczy zaprzeczyć biologii ${ }^{33}$.

Neodarwiniści uważają naturalną selekcję za główny filar ich teorii ewolucji. J. Huxley oddał to słowami, że końcowym efektem naturalnej selekcji jest to, że każda istota zmierza zgodnie $\mathrm{z}$ warunkami, w których żyje, zawsze do tego, by być doskonalszą. To doskonalenie prowadzi nieuchronnie do postępu organizacji większej części istot żywych. Grassé uważa, że Huxley nie wyciągnął logicznych wniosków ze swej argumentacji. Darwinowski bowiem system, wykluczając celowość na rzecz przypadku, w rzeczywistości przypisuje implicite rozstrzygającą rolę metafizycznej zasadzie korzyści. Tylko to, co jest korzystne, jest zachowane, przeto $\mathrm{w}$ konsekwencji nasz świat odpowiada celowi. Ukryty finalizm przenika więc darwinowską doktrynę i ukazuje się jako ,egzystencjalna podstawa" ewolucji. Końcowym celem ewolucji jest ustanowienie doskonałej równowagi między żyjącą istotą i środowiskiem, przy pomocy dostawy materiału, który jest dostarczany przez przypadek, a jest sortowany przez selekcję ${ }^{34}$.

Autor przyznaje, że jeżeli idzie o możliwość rozróżnienia między „,dobrym” i ,złym” przystosowaniem, to nie można wykluczyć subiektywnych sądów w tym względzie. Mogą bowiem istnieć przeciwne zdania w odniesieniu do tego samego zjawiska. Przy pomocy badań morfologicznych, chociaż są dokładne, nie można precyzyjnie osądzić stopnia przystosowania organu czy całej istoty żywej. Różnica zdań między finalistami i antyfinalistami polega często na trudności osądu, co jest pożyteczne, a co nie dla organizmu. Próbuje się obejść tę trudność przy pomocy statystyki. Oblicza się pożyteczność jakiegoś organu czy fizjologicznego procesu według ilości potomstwa badanej pary. Jeszcze większa trudność zachodzi w ocenie dobrego czy złego przystosowania, jeżeli bierze się pod uwagę wszystkie gatunki tego samego biotopu. Trudno np. powiedzieć, który gatunek żyjących $\mathrm{w}$ danym akwenie ryb jest najlepiej przystosowany. Największe trudności zachodzą, gdy porównujemy ze sobą różne linie rozwojowe, np. salamandry i węże $\mathrm{z}$ istotami czworonożnymi. Tylko prowadzone przez długie lata badania i oparte raczej na bilansie całego życia niż cech, mogą przynieść odpowiedź ${ }^{35}$. W świecie nieożywionym nie jest dane ani dobro ani zło. Dokonanie się czy niedokonanie zjawiska zależy tylko od niezmiennych praw. Natomiast utrzymanie i przekazy-

33 Tenże, Das Ich, s. 54.

34 Tenże, Evolution, s. 171, 186.

35 Jw., s. $97,186-187$. 
wanie życia stawia ipso facto problem celowości w formie korzyści dla istoty żyjącej ${ }^{36}$.

\section{WNIOSKI}

Można wyróżnić dwa zasadnicze stanowiska biologów i filozofów wobec roli celowości i przypadku w przyrodzie. Pierwsza grupa przypisuje przypadkowi wiodącą rolę w powstawaniu i rozwoju życia. Gdyby przypadek działał inaczej w przeszłości, to ewolucja miałaby zupełnie inny przebieg, a obecny świat wyglądałby inaczej. Czołowymi przedstawicielami tego poglądu są J. Monod i R. W. Kaplan. Druga grupa biologów ujmuje celowość i przypadek jako dwa komplementarne, czyli współdziałające ze sobą czynniki. Koncepcja celowości Grassé należy do drugiej grupy poglądów ${ }^{37}$. Zwolennicy drugiej grupy poglądów różnią się między sobą w podziale ról obu czynników. Grassé maksymalizuje rolę celowości, natomiast przypadkowi przypisuje tylko drugorzędną rolę. Przypadek nie może stanowić napędowej siły ewolucji, gdyż w zasadzie prowadzi do zmian tego, co już istnieje i nie jest czynnikiem powstawania nowych osiągnięć w naturze; tym bardziej że przypadek nie jest niczym innym, jak niemożliwością przewidywania serii zdarzeń, a więc przypadek nie wyklucza determinizmu.

Grassé opowiada się zdecydowanie za istnieniem wewnętrznej celowości w przyrodzie. Tym celem jest dobro organizmu na wszystkich poziomach bytu. Wewnętrzną celowość widzi autor w samym powstaniu życia i w każdym zjawisku życia. Życie powstaje przez organizację, równowagę i porządek wewnątrz złożonej i heterogenicznej struktury organizmu. Celowość wiąże się z każdą czynnością organizmu i można ją nazwać samym życiem. Immanentna celowość, podobnie jak przypadek i porządek, godzi się doskonale $\mathrm{z}$ determinizmem w naturze. Celowość w przyrodzie jest - według autora - tak oczywista, że nawet jej przeciwnicy zakładają ją przynajmniej jako hipotezę roboczą w swych badaniach istot żyjących. Także w opisie zjawisk życia, chcą czy nie chcą, posługują się słownikiem, który jest w wysokim stopniu finalistyczny.

Równocześnie autor zachowuje naukowy krytycyzm. I tak przyznaje, że nie można uniknąc subiektywnych sądów w ocenie korzystnego czy niekorzystnego przystosowania się organizmu do otoczenia. Zdaje sobie sprawę, że uznanie istnienia wewnętrznej, czy lepiej się wyrażając, faktycznej celowości w świecie istot żywych, nie musi prowadzić do uzna-

36 JW., s. 186.

37 T. W o jciechowski, Przypadek $i$ celowość $w$ ewolucji biologicznej, [w:? $Z$ zagadnień filozofii przyrodoznawstwa $i$ filozofii przyrody, t. 1, Warszawa $1976_{\text {. }}$ s. $329 \mathrm{n}$. 
nia istnienia przyczyn celowych w świecie biologii. Choć wyraża się ostro o braku widzenia celowości przez antyfinalistów, to jednak nie czyni im wyrzutów za ich hipotezy i terminologię. Wykazuje im tylko, że nieświadomie tak postępują, jakby uznawali istnienie tej celowości. Dodać należy, że według Grassé problem celowości i przypadku w przyrodzie nie jest wcale problemem pozornym, przeciwnie - jest problemem realnym i czeka na racjonalne rozwiązanie.

Grassé dystansuje się wyraźnie od filozoficznej interpretacji celowości w przyrodzie. W wielu miejscach swej książki Das Ich und die Logik der Natur wyraża się krytycznie o pewnej grupie filozofów, która neguje istnienie celowości w świecie. Jeżeli filozof mówi, pisze Grassé, że świat i człowiek są absurdalni (bez celu), to zachowuje się jak dziecko ${ }^{38}$. Grassé nie chce wychodzić poza wnioski biologiczne. A więc nie pyta o przyczyny celowe w naturze, nie mówi o celowości transcendentnej. Nie ekstrapoluje wewnętrznej celowości organizmów na cały wszechświat i na istnienie porządkującej siły. Nie pyta o „dlaczego" przedmiotów i o ich rolę w całości kosmosu. Do czego bowiem, pisze, ma służyć badaczowi pytanie o „dlaczego" rzeczy? Wystarczy rozważać skarb przyrodniczego poznania, aby dojść do przekonania, że w całym wszechświecie panuje porządek. Taki sposób postępowania świadczy jego zdaniem o mądrości i skromności badacza. Z drugiej strony wierzy, że takie stanowisko prowadzi samo z siebie do rozwiązania ważnych filozoficznych problemów ${ }^{39}$. Doprowadza bowiem do granicy biologicznych badan, poza którymi otwiera się w jakiś sposób dziedzina filozofii. W człowieku bowiem jest naturalne dążenie do transcendencji, która wyprowadza go poza to, co jest materialne i przypadkowe.

\section{KONZEPTION DER FINALITÄT IN DER NATUR NACH P. P. GRASSE}

Zusammenfassung

P. P. Grassé sieht in der Frage, welche Rolle die Finalität und der Zufall in der Natur spielt, kein Scheinproblem, sondern eines der Hauptprobleme der Biologie. Die Analyse der biologischen Tatsachen führt unseren Autor zur Feststellung der universellen Ordnung, der Finalität und des Determinismus im ganzen Bereich der Lebewesen. Sogar die Aussagen der Antifinalisten interpretiert Grassé im Sinne der immanenten Finalität. Auch das Auftreten der zufälligen Phänomene widerspricht nach ihm nicht dem universellen Determinismus und der Finalität in der Natur. Grassé maximalisiert im allgemeinen die Rolle der Finalität in der Natur und minimalisiert die Rolle des Zufalls.

38 P. Grassé, Das Ich, s. 224.

39 Tamże, s. 221. 